\title{
CHANGES TO THE RED SNAPPER FISHERIES IN THE ARAFURA SEA FISHERIES MANAGEMENT AREA
}

\author{
Siti Nuraini and Tri Ernawati \\ Research Institute for Marine Fisheries, Muara Baru-Jakarta \\ Received November 26-2008; Received in revised form April 16-2009; Accepted May 18-2009
}

\begin{abstract}
Red snappers are target species and exploited by industrial fisheries off the Bottom longline, trap and as by product of fish net in Arafura Sea. This study proposed to identify effect of industrial fishing on red snapper fishery; on size and catch composition. Data used in this study were catch data of bottom longline and trap landed in October-December 2004; landing data of the bottom longline and trap in 2005-2007, fish net catch data landed in Merauke. Information on day trips, number of vessel, number of fishing gears was gathered from fishing port Tenau, Kupang, Fisheries District of Probolinggo, and interviews to the captain and crew of bottom longline. Changes in the fishery of red snapper is define by comparing present fishery to those off ACIAR/RCCF Red Snapper research collaboration 1999-2002. Results of the study showed changes in the vessel size, gear size and number, and trip duration in red snapper fishery. The fishing vessels sized of bottom longline changes from higher than 70 GT to lower than 50 GT. Hook size from no.4-5 shift to 5-8. Day at sea decline from approximately 3-4 months per trip to aproximaly one month per trip. In total number of trip decrease from 3-4 trips per year decline to 4-6 trips per year. The catch composition of red snapper, L. malabaricus was decline from $47 \%$ in 2005 to $24.3 \%$ in 2007 of the total catch. Deep sea snapper, Pristipomoides multidens was caught $16.1 \%$ in 2005 increased to $36 \%$ in 2007 . The length at firts capture of $L$. malabaricus decreased from $50.7 \mathrm{~cm}$ in 2001 to $41 \mathrm{~cm}$ in 2007.
\end{abstract}

KEYWORDS: $\quad$ red snapper, catch composition, size structure, bottom longline, trap, fish net, Arafura Sea

\section{INTRODUCTION}

Red snappers species are belong to the family Lutjanidae. The fresh fish are easy to recognise from their colour, started from jellow to reddish, bright red, dark red to brownish. The family of Lutjanidae consisted of 9 genera, which include Lutjanus, Pristipomoides, Pinjalo, Aphareus, Etelis, Aprion, Symphorus, Symphorichthys, and Macolor (Allen, 1985). Except for the last genus with only one species called Macolor niger which is black in colour, other genera having several colour pattern from bright reddish, yellowish/greenish to dark brownish. In most part of the Indonesian waters the first two genera provide the most dominant catch.

The term red snapper or 'kakap merah' in the field seem to be applied only to the genera Lutjanus and Pinjalo. Mc Pherson et al. (1992) categorized three species of snapper as the red snapper; i.e. red emperor ( $L$. sebae), Scarlet sea perch ( $L$. malabaricus) and Saddletail sea perch ( $L$. erythropterus). Other genera such as Pristipomoides, Aphareus, Etelis, Aprion, Symphorus, Symphorichthys, and Macolor are never considered as red snapper even though the colour is bright reddish, such as Etelis carbunculus. Goldband snapper, (Pristipomoides sp.) or deep-water snapper with its popular name as kurisi bali that by some fishers called as anggoli, is likely come from the Singapore market name as angkoh li.

Most of Lutjanids fish especially the laige size provide the most economically important fish. Of the lutjanid fish, the species Lutjanus malabaricus, $L$. erythropterus, L. bohar, L. argentimaculatus, L. monostigma, L. timorensis, L. gibbus, L. lemniscatus, $L$. Sebae, and Pinjalo pinjalo provide the common red snapper found in the Indonesian. In Kupang and Sape, scarlet snapper, L. malabaricus found matured at $41,3 \mathrm{~cm}$ TL and red emperror, L. sebae (Andamari et al., 2004). The length at $50 \%$ maturity of $L$. malabaricus, L. sebae, L. eryththropterus was reported from the Great Barrier Reef at 54.8, 57.6, and $48.6 \mathrm{~cm}$ in SL each, respectively (McPherson et al., 1992, McPherson \& Squire, 1992).

Lutjanids are key species in the coral reef ecosystems (Parish, 1987) and major resources for tropical fisheries. They are exploited by industrial line fisheries for local and export market in Indonesia, Australia and Caribbean (Clark \& Loyd, 2002; Mendoza \& Larez, 1996; Badrudin et al., 2004; Nuraini, 2007). Exploitation by artisanal fisheries directed on them with moderate and heavy fishing pressure being both selective and powerfull active gears in reefs (Herianti \& Djamal 1993; Munro, 1967) and seagrass beds 
In the framework of the ACIAR/RCCF Red Snapper research collaboration 1999-2003, three red snapper species have been intensively studied, the scarlet snapper Lutjanus malabaricus, red snapper, $L$. erythropterus, and goldband snapper, Pristipomoides multidens. The main finding of this research was that through the genetic characteristics of the mIDNA, it was concluded that the three species distributed in both Australian and Indonesian sectors of the Arafura Sea were belong to the same stock. Furthermore, Salini in Andamari et al., 2004 stated that the red snapper, L. malabaricus from Arafura, Kupang, Tanimbar, Aru East Australia, Groote, and Weipa are from one stock. Consequently, these species should hopefully be exploited and managed appropriately if the two countries wish to exploit these resources sustainably

This paper attempt to review the red snapper fisheries in the Arafura Sea Fisheries MagamenetArea, with special references to up date the results of the ACIAR-RCCF research collaboration 1999-2003.

\section{MATERIALS AND METHODS}

In this study data analyzed were used catch data of 15 boats of bottom longline of trap landed in OctoberDecember 2004, catch data from 1977 boats of bottom longline and trap in 2005-2007 based in landing site Probolinggo, fish net catch data landed in Merauke. Information of day trips, number of vessels, number of fishing gears were gathered from fishing port of Tenau, Kupang, Fisheries District of Probolinggo and interviews with the captain and crews of bottom longline vessels. Catch data information includes, fleets name, company name, fishing gear, period of fishing, catch by species in local name in biomass. Catch and composition of red snapper in fish net was based on Merauke Fisheries District in 2005 and 2006.

Changes of in the fishery of red snapper is define by comparing present fishery to those the results of the ACIAR-RCCF research collaboration 1999-2003.
Size of the dominant snapper i.e. Lutjanus malabaricus, L. erythropterus, L. sebae, Pristipomoides multidense, and P. typus were collected from landing site of Probolingo in March, July, and December 2007.

\section{RESULTS AND DISCUSSIONS}

\section{Number and Size of Vessels}

Information obtained from the licensing division of the Direcorate General of Capture Fisheries, regarding the number of license fishing vessel of $>30$ GT used by the boat targeted for pelagic fish and five fishing gear targetted on demersal fish group. The following five fishing gears targetted on demersal fish group was presented in Table 1. The number of fishing gear were dominated by the fish net, shrimp net and bottom longline. All the fishing boats were belong to the industrial scale of fisheries.

It is likely that for all of the licensed fishing vessel using fishing gear listed in the Table 1, the target species are not stated in each of the license. The license just only listed of one or more species group, such as pelagics group, demersal; but not for example, red snappers, groupers, and scads except shrimp. Concern sometimes proposed by the shrimp trawlers regarding their catch. It is commonly known that the shrimp tralwers are not allowed to catch and to land or to unload fish in substantial amount according to the inspectors. On the other hand, the catch of fish trawl or fish net consisted of many species group including pelagic fish, demersal fish, shrimp, squids, and others.

Arafura Sea fisheries as a whole were dominated by the fish net (fish trawl), shrimp trawl, and oceanic gill net fisheries. Fish net and shrimp net operate their gear in almost overlapping fishing ground, while the oceanic gill net seems to be operated in the offshore waters and targetted for large pelagics species. Except for fish net, shrimp net, and bottom longline,

Table 1.

Number of licensed fishing vessel operated in the Arafura Sea issued in May 22, 2007

\begin{tabular}{lcccccc}
\hline \multicolumn{1}{r}{ Fishing gear } & \multicolumn{7}{c}{ Range GT } & \multirow{2}{*}{ Total } \\
\cline { 2 - 6 } & $<50$ & $\mathbf{5 1 - 1 0 0}$ & $\mathbf{1 0 1 - 2 0 0}$ & $\mathbf{2 0 1 - 4 0 0}$ & $>\mathbf{4 0 0}$ & \\
\hline Demersal & 8 & 3 & - & - & - & 11 \\
1. Traps & 2 & 1 & - & - & - & 3 \\
2. Bottom gill net & 117 & 30 & 6 & 4 & & 157 \\
3. Bottom longline & 2 & 3 & 167 & 359 & 119 & 648 \\
4. Fish net & 123 & 165 & 20 & 9 & 319 \\
5. Shrimp net & 129 & 160 & $\mathbf{3 3 8}$ & $\mathbf{3 8 3}$ & $\mathbf{1 2 8}$ & $\mathbf{1 1 3 8}$ \\
\hline Total & & & & &
\end{tabular}


no catch sample collected from the others fisheries that can be used as an anchor point for further assessment of the fishery.

Looking at the total number of licensed fishing vessel of 1,137 boats, it is likely that these number is considered high compare to licensed fishing vessel operated in the Australian sector of the Arafura Sea. Apart from the licensed fishing vessel, it is concerned that until the end of 2007 or probably until the present time there were some illegal fishing vessel operated in the Arafura Sea

\section{Development of Trap and Bottom Longline Fleets}

The trap fishery in Arafura Sea by the fleets from Tanjung Balai Karimun in 2004 was recorded; however no information on the development of this activity was reported. They operated about 250,700 , or 1,000 unit of trap depending on the size of vessel. The trap was made of iron bars of concrete of $10 \mathrm{~mm}$ diameters, constructed in a cube form and covered with PA net of 2 inches mesh size. The average size of the cube trap was $140 \times 90 \times 60 \mathrm{~cm}$, with mouth width about 56 $\mathrm{cm}$ and the length of the cones of about $90-100 \mathrm{~cm}$. The trap fishing gear is usually operated in a series of about $7-10$ units/series at the depth of $40-60 \mathrm{~m}$. Fishing period in sea per trip was 14 days and effective fishing operation was 7 days per trip. The number of trap was accounted for 34 boats in 2004 decrease to 11 boats in 2007 (Table 2). Decline in trap vessels due to the shift to bottom longline vessels as hundreds of trap was lost in the fishing ground.

The total number of bottom longline in 2001 was reported to be 33 boats (Anonymus, 2003) increase to be aproximately 217 vessels in 2004 and by 2007 decrease to 187 vessels in 2007 (Anonymus, 2007). Reduction in number of bottom longline fishing vessels due to firstly they were caught by the of Australian Goverment as entered the Australian waters. and secoondly by the increase of fuel price that tend to inrease operational cost. It is likely that aproximately half of the total number vessels were stop fishing.

Effect ffuel increase altered the bottom longline fishery system has caused decreased in the size of fishing vessels, fishing day, hook size, and its number (Table 3). The size of catcher of bottom longline changes from 70-120 GT to 30-70 GT, as cost operation of large vessels is higher than small boats. With the lower capacity of fishing vessels, catches were transshipped in the sea or in harbor into a fish carrier and transported to Probolinggo. This activities were carried boats out at sea or in Wanam (the ex Jayanti Group fishing base) or in Kupang fishing port. Total number of hooks showed increase between 2,500-3,000 hooks, with most of them used 3,000 hooks. The size of hook varied for no. 5.5-8.

The total number of fishing days of bottom longline in the sea decrease from three to four months to 8-30 days per trip. In 2007, bottom longline made about 46 trips per year; formerly they made 3-4 trips per year. On average bottom longline managed $17.6 \pm 6.74$ days per trip (Syahasta et al., 2007) with one setting per day, in the evening or in the morning. Fishing trip in the Arafura Sea usually carry out in December to April, while in the Timor Sea from April-November. The baits used for bottom longline were sardines, scads or tunalike fish loaded from Probolinggo with the average about $3-4$ tones/trip.

\section{Fishing Ground}

Exploitation of fish resources in the Arafura Sea have been carried out for years by the industrial scale fisheries. For about the last twenty five years, the shrimp trawlers, fish trawlers (fish net), and bottom longliner provide the most active fisheries in this waters. Except for bottom longline fisheries that has different fishing ground, the shrimp trawl and the fish

Table 2. Development of trap and bottom longline vessels in landing site of Probolinggo, East Java

\begin{tabular}{lccccc}
\hline \multicolumn{1}{r}{ Fishing boat by gear } & \multicolumn{5}{c}{ Development } \\
\cline { 2 - 5 } & 2001 & 2004 & 2006 & 2007 & Status \\
\hline No. Trap vessels & - & 34 & 14 & 11 & decline \\
No. BLL vessels & 33 & $\pm 217^{\star}$ & - & 187 & Up and Down \\
\hline
\end{tabular}

Notes: * Based on interview on the BLL manager/agent

Table 3. Changes of fishing vessels and hooks size of bottom longline fishery in Arafura Sea in the period 1999-2002 (ACIAR/RCCF) and present study

\begin{tabular}{lcccc}
\hline & Boat size (GT) & Hook no & Size of hook & Day in sea/trip \\
\hline $1999-2002$ & $70-120$ & $1,800-2,900$ & $4-5$ & $45-60$ \\
Recent study & $30-70$ & $2,500-3,000$ & $5.5-8$ & $8-15$ \\
\hline
\end{tabular}


trawl have almost operated in the same fishing ground. The fishing ground of bottom longline fisheries that can be considered as selective fishing gear are usually operated in the muddy coral habitat with a relatively larger size demersal finfish as the target species group.

The fishing ground of the bottom longline landed in Probolinggo covered the waters of the Arafura Sea, Aru Sea, Seram Sea, Dobo, Avona, Timor Sea, Flores Sea, and Java Sea. They usually covered three or four fishing grounds in one trip in coral reef flat or slope with a relatively larger size demersal finfish as the target species group. The fishing ground of trap fishery covered the reef slopes and shelves waters of the Arafura Sea, Aru Sea, Timor Sea, and Java Sea (Masalembo, Matasirih). The depth of bottom longline was reported at reef slope at 64-125 m depth with bottom substrate sandy mud, whereas fish net fished at 35-52 m depth in sandy mud area. The fishing area of trap was reported reef area adjacent to reef island in Aru Island, Timor, Fak-Fak to Masalembo, Java Sea (Anonymous, 2003).

\section{Fishing Port}

For the three industrial scale fisheries of fish trawlers, shrimp trawler and bottom longline that have been operated for years, almost no change in their fishing base. The fish trawler or fish net fishing base are Tual, Wanam, Sorong, Merauke, and Ambon. Tual fishing port has long been used by some fishing companies. Some large fishing companies have their own fishing port/landing site.

In Merauke, as the capital city of the Merauke District, there are some branch office or agents of some fishing companies. These agents usually managed license supply all necessary provision needed to support fishing operations. Some biological data of red snappers have been collected during this study in Merauke. Most fish were caught by fish trawlers, some of fish were collected from the Laboratory of Fish Quality Controle.

Wanam is a fishing base built by Jayanti Group. It is likely that nowdays this port has been used by some others fishing boats from different companies either for unloading catch, fish/catch collectors, and to get some provisions (drink water, ice, vegetables etc.).

Sorong is one of the large fishing base for shrimp trawlers since the Arafura Sea shrimp fisheries began in the $1968-70^{\text {th }}$. It is also provide the fishing base of the former PT. Usaha Mina, the tuna/skipjack fishing base that in the late 1980 has also operate their boat ton catch red snappers and some large demersal fish.

Kupang and Probolinggo provide a transit fishing base of bottom longline fisheries operated by their headquaters in Tanjung Balai Karimun. The bottom longline fishing boats stop over in Tenau Coastal Fishing Port for collecting provisions for and from fishing operation in the Timor Sea and Arafura Sea. Some bottom longline fishing boats back from the Arafura Sea usually unloaded part their catch especially fish that having lower market prices. Some first quality fish of scarlet snapper, $L$. malabaricus and goldband snapper, P. multidens, are usually transported to TBK, and directly exported.

\section{Catch Composition}

Information on catch composition is one of the aspects for biomass assessment. Changes in catch composition may involve in shift biomass or sizespecific biomass off different trophic groups. Shift in catch compsition can be used as one index of the extended exploitation in reef fisheries. In light fishing intensity catches consist of large predator fishes i.e. grouper and snapper in bottom long lining catches. As the fishing pressure increase, catches of predator fish decline and replaced by small emperors (Jenings \& Lock, 1996). Overall catch were recorded 70 fish categories in local name. The dominant catch were recorded deep-sea snapper or locally Angoli (36\%), red snapper $(24.7 \%)$, Carangid (putih) $10 \%$, and grouper (kerapu) $9 \%$

\section{Trap catch composition}

Catches of trap off the Tanjung Balai Karimun fleets in October-November 2004 ranged from the lowest $2,143 \mathrm{~kg}$ and the highest of $11,876 \mathrm{~kg}$ per trip per boat. The mean catch of red snapper was about 5,324 $\mathrm{kg}$ per trip per boat. Red snapper dominated catches for $22.7-69.5 \%$ of the trap catches. On average red snapper dominated $40.3 \%$ of the overall catches. Goldband snapper were caught on average $5.7 \%$ of the total catch (Figure 1). L. erythropterus caught very small contributed for $6.5 \%$ of the overall trap catches. No record on shift in catch composition from this area.

\section{Bottom longline catch composition}

Total catches of the bottom longline of the Tanjung Balai Karimun fleets in October-December 2004 varied from lowest $566-14,505 \mathrm{~kg}$ per trip per boat. The average red snapper catches provide $3-93 \%$ of the overall catch. The average catch of red snapper contributed $40,4 \%$ of the total catch. Goldband 
snapper provided from $0.4-79 \%$ of the total catch. On average goldband snapper contributed $27.1 \%$ of the total catch (Figure 2). High variation in catch composition of snapper in trap and bottom longline might be due to fishing activity was conducted in several places, i.e. Arafura Sea, Timor Sea, and or Flores, Seram and Macassar strait with diffrent habitat and abundance of the fish. Other reason might be due to effect of misrecorded on catch data. The catch reported by this company (Anonymus, 2005) operated in the continental shelf of most area of the eastern Indonesia region including Arafura, Seram Sea, and others, consisted of $58 \%$ red snappers (Lutjanus spp.), $16 \%$ goldband snapper (Pristipomoides spp.), and $7.8 \%$ groupers (Serranidae) and others.

\section{Fish net catch composition}

Total landing of red snapper from catcher of Thai fishnet vessels in Merauke in 2005 accounted for 254.43 tonnes and in 2006 for 456.98 ton. The most dominant catches in fish net were scads $(10.7 \%)$, seabream, Nemidterids ( $9.7 \%)$, and cat fish $(8.8 \%)$. Overall mean catch of snapper was found to be 41 $\mathrm{kg} /$ day/trip. Red snapper accounted for $1.1 \%$ of the total catch in biomass. The mean catches of snapper in 2005 was found to be $31 \mathrm{~kg} /$ day/trip and in 2006 for
$42 \mathrm{~kg} /$ day/trip. Daily catches of overall snapper in 2005 and 2006 , ranged from $11 \mathrm{~kg} /$ trip/day to $53 \mathrm{~kg} /$ trip/day.

A similar result was reported by Badrudin et al., (2004). They stated that sea breams (Nemipteridae), lizard fish (Synodontidae), and cat fish (Scianidae) were caught dominant among demersal fishes in fish net in Arafura, whilst Chub mackerel (Rastreligerspp.) and Cephalopods dominated pelagic fish. Red snapper was caught for less than $2 \%$ of the total catch. Similarly, fish net in Arafura Sea of the Australian license dominated by Sea breams groups in 19721979 (Ram \& Xiao, 1996).

\section{Shift on red snapper catch composition}

Based on landing data of 1977 fleets base of bottom longline and trap catches in Probolinggo from 20052007 , it showed some changes in catch composition in term of biomass of red snapper and deep sea snapper (Table 2). The red snapper catches decline from $42.1 \%$ in 2005 to $24.7 \%$ in 2007 . Catches of goldband in bottom longline catches increase from $16.1 \%$ in 2005 to $36 \%$ in 2007 of the total catch.

Changes in catch composition of red snapper and deep sea snapper in term of biomass in the last

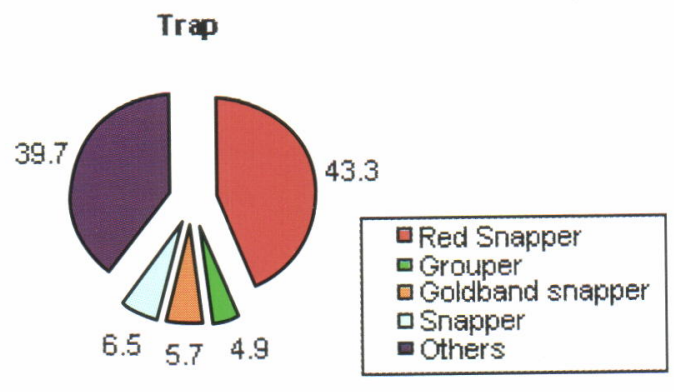

Figure 1. Catch composition of red snapper and goldband snapper in trap fisheries from OctoberDecember in 2004 landed in Air Tembaga, Probolinggo, East Java.

Bottom Long Line

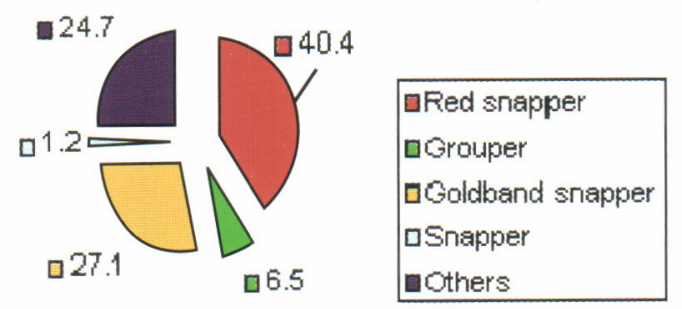

Figure 2. Catch composition of red snapper and goldband snapper in bottom longline fishery from October-December in 2004 landed in Probolinggo, East Java. 
decade was detected (Table 4). The red snapper catches decline from 58\% in 1995 (Usaha Mina report) reduced to $42.1 \%$ in 2005 and to $24.7 \%$ in 2007 Catches of Goldband, P. multidense in bottom longline catches in 1995 is the same as in 2005 for $16 \%$. By 2007 catches increase to be $36 \%$ of the total catch. Badrudin \& Blaber (2003), reported red snapper found for $21,3 \%$ and $P$. multidens for $1.1-5,1 \%$ of total catch in Aru Sea. Variability in red snapper composition in bottom longline catches might be affected by variability in the fish abundance, habitat structure of fishing ground, environmental condition, seasonal, and technical interaction in the red snapper fishery.

Lowered in red snapper catches is followed by increasing of other species such as deep sea snapper, however often followed an increase of carangids, or emperor. In initial fishery, catches targeted for large predator fish (snapper and grouper), later fishery, catches shift from large predator fishes to small emperors dominated in lining fishery (Jenning \& Lock, 1996)

\section{Size distribution}

Bottom long line is probably the most commonly fishing gear to catch reef fishes and select mainly large predator species such as snapper and grouper. The size of the fish caught influenced by size of gear
(Ralstone, 1990). Large size of hook tend to catch larger fish and smaller hook size caught smaller fish.

The red snapper species collected in landing base, were between $22-75 \mathrm{~cm}$ in TL. The dominant snapper $L$. malabaricus were recorded at 22.5-75 cm; $L$. erythropterus between $30.5-50.5 \mathrm{~cm}$, and L. sebae between 38.5-64.5 cm in FL. Deep sea snapper of the species $P$. multidense recorded at size between 26.5-65 $\mathrm{cm}$ and smallest size was $P$. typus between 22.5-52.5 cm in TL.

Length at first capture (Lc), with assumption that the samples were proportion to the fish population, it is likely that size structure of snappers decline in the last decade (Figure 3, Table 5). Looking at $\mathrm{LC}_{50 \%}$ of each red snapper species, it appeared that most of red snapper caught were of immature fish and young brood stock. In contrast to catches in the period 19992002, most of the snapper that caught were old brood stock at size higher than $60 \mathrm{~cm}$ in TL (Badrudin et al., 2004).

Unlike off bottom longline, red snapper catches in fish net in Merauke showed similar size ranged in recent study to earlier study reported by Badrudin \& Blabber (2003). At present, the red snapper size ranged between $22-78 \mathrm{~cm}$, with modus at length class at 26-27 cm contributed for $23 \%$. Badrudin \& Blabber

Table 4

Changes on red snapper and goldband snapper in 1995-2007. Data was gathered from Usaha Mina, ACIAR and Landing in (2007)

\begin{tabular}{|c|c|c|c|c|c|c|}
\hline \multirow{2}{*}{$\frac{\text { Local name }}{\text { CPUE (kg/trip/boat) }}$} & \multirow[t]{2}{*}{ Scientific name } & \multicolumn{5}{|c|}{$\%$ catch composition } \\
\hline & & $1995^{\star}$ & ACIAR & 2005 & 2006 & 2007 \\
\hline Kakap merah & L. malabaricus & 58 & 47.3 & 42.1 & 30.8 & 24.7 \\
\hline Kakap seto & L. erythropterus & & & 0.4 & 0.8 & 4.84 \\
\hline Kakap sawo & L. sebae & & & & 0.3 & 0.74 \\
\hline Tungku & Lutjanussp. & & & 0.2 & 0.8 & 0.8 \\
\hline Angoli & P. multidense. & 16 & & 16.1 & 25.1 & 36 \\
\hline
\end{tabular}

Notes: * based on Usaha Mina; ** ACIAR 1999-2002

Lutianus makbaricus

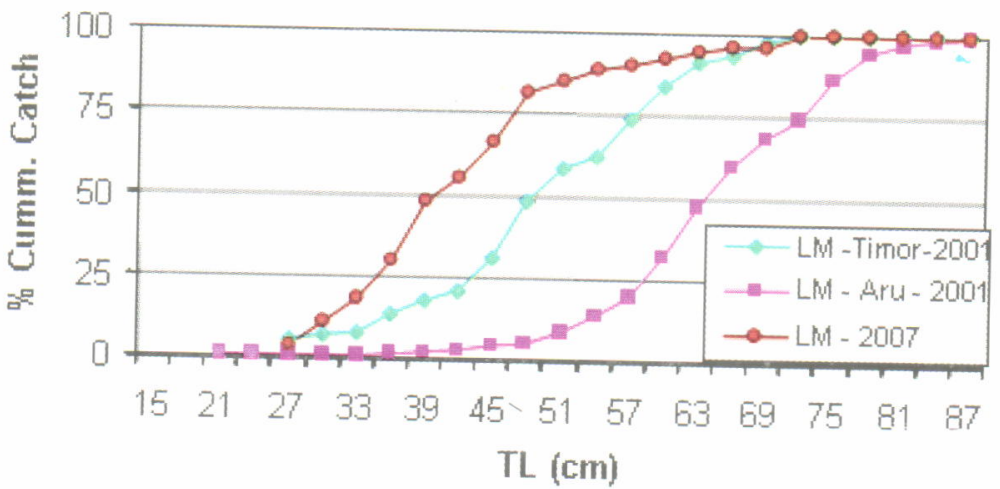

Figure 3. Changes in length at first capture of red snapper (Lutjanus malabaricus) in 2001-2007. 
Table 5. The length ( $\mathrm{cm}$ in TL) at $50 \%$ capture of the $L$. malabaricus, L. erythropterus, and $P$. multidense caught in Arafura Sea in landing site in Probolinggo, East Java

\begin{tabular}{lccc}
\hline & $\mathrm{LC}_{50 \%}$ in $2000 / 02^{*}$ & $\mathrm{LC}_{50 \%}$ in $2007^{\star *}$ & $\mathrm{Lm}_{50 \%}(\mathrm{~cm})^{\star \star *}$ \\
\hline Bottom longline & 50.7 and 67.3 & 41 & 54.8 \\
L. malabaricus & 59 & 39 & 48.6 \\
L. erythropterus & 53 & 45 & 57.6 \\
L. sebae & 43.4 and 69 & 40.5 & \\
P. multidense & 27.1 & $26-27$ & 54.8 \\
Fish net & L. malabaricus in Merauke &
\end{tabular}

Sources: *ACIAR; ** Landed in Probolinggo in 2007; *** in McPherson et al. (1992), McPherson \& Squire (1992)

(2003) reported red snapper caught by fish net from Arafura in 2002 was recorded to be $27.1 \mathrm{~cm}$.

\section{CONCLUSION}

1. Changes in fishing effort and size of bottom longline fleets have been observed since 2005. The size of vessel shift from higher than 70 GT to lower 50 GT. Using smaller fishing vessel cause shorter in fishing day. Hook size shifted to smaller size but the number of hook increased.

2. Shift in catches of red snapper and deep sea snapper of bottom longline fishery was recorded and was likely as the results of high exploitation.

3. Smaller size of red snapper and gold band snapper in Arafura management area was observed. Decrease in size structure of red snapper from large adult brood stock to immature and young brood stock could be probably due to effect of over fishing.

\section{ACKNOWLEDGEMENT}

This study is based on data collected within the fisheries component of in house project of assessment on fishery resources and its ecology in Arafura Sea in 2007 funded by the Research Institute for Marine Fisheries Jakarta. The authors thank to Prof. M. Badrudin for his support and valuable idea for this paper.

\section{REFERENCE}

Andamari, R., D. V. D. Milto, T. Velde, \& B. Sumiono. 2004. Observation on reproducive biology of red snapper (Lutjanus malabaricus) from Sape and Kupang waters. Jurnal Penelitian Perikanan Indonesia. 10 (4): 65-75. (In Indónesian).
Anonymous. 2003. Report of the final ( $\left.4^{\text {th }}\right)$ stock assessment workshop. ACIAR Red Snapper Project. Puncak Pass. Cianjur. Indonesia.

Anonymous. 2005. Komposisi Hasil Tangkapan Rawai Dasar (Bottom Longline) di Laut Arafura. Interim Report Usaha Mina.

Anonymous. 2007. Perizinan Kapal Laut di Laut Arafura. Direktorat Pelayanan Usaha Penangkapan Ikan. Direktur Jenderal Perikanan Tangkap.

Allen, G. R. 1985. Snappers of the world. FAO species catalogue. FAO Fisheries Synopsis. Rome. 125 (6): $208 \mathrm{pp}$.

Badrudin \& S. Blabber. 2003. Pengkajian stok sumber daya ikan kakap merah di perairan : aut Arafura dan Laut Timor. In Prosiding Forum Pengkajian Stok ikan Laut 2003 WPP Samudera Hindia, Laut Arafura, Laut Cina Selatan, dan Laut Jawa. Pusat Riset Perikanan Tangkap. Badan Riset Kelautan dan Perikanan. Departemen Kelautan dan Perikanan. Jakarta, 23-24 Juli 2003. 47-55.

Badrudin, B. Sumiono, \& S. Nurhakim. 2004. Hook rate and compositions of bottom longline catches in the waters of the Arafura Sea. Indonesian Fisheries Research Journal. 10 (1): 9-14.

Clark, J. \& Loyd. 2002. Offshore tropical Snapper Fishery. Fish Note.29, January 2009. Marine Fish Research Scientist. Darwin. http://www.nt.gov.au/ $\mathrm{d} /$ Content/File/p/Fishnote/FN29. Date of acces in November 8, 2008.

Herianti, I. \& R. Djamal. 1993. Dinamika populasi kakap merah, Lutjanus malabaricus Bloch \& Schneider di perairan Laut Utara Jawa. Jurnal Penelitian Perikanan Laut. 78: 18-25. 
Jennings, S. \& J. M. Lock. 1996. Population and ecosystem effects of reef fishing. In Reef Fisheries. Ed. Nicholas, V. C. \& C. M. Roberts.

Ralston, S. 1990. Size selections of snappers (Lutjanidae) by hook and Line gear. Canadian Journal Fisheries Aquatic Science. 47: 696-700.

Ram, D. C. \& Y. Xiao. 1996. Catch, effort, and sustainable yield for Australia Northern trawl fishery. In Sanchez, A. F., J. L. Munro, M. C. Balgos, \& D. Pauly (eds). Biology, Fisheries, and Culture of Tropical Groupers and Snappers. ICLARM Conf. Proc. 48: 289-306.

Munro, I. S. R. 1967. The fishes of New Guenia. Dep. of Agricultured, Stock, and Fisheries, Port Moresby. New Guinea. 651 pp.

McPherson, G. R. L. Squire, \& J. O'Brien. 1992. Reproduction of three dominant Lutjanus Species of the Great Barrier Reef. Inter Reef Fishery. Manila. Philippines Asian Fisheries Science. 5: 15-24.

McPherson \& Squire. 1992. Age and growth of three dominant Lutjanus species of the great barrier reef.
Inter Reef Fishery Asian Fisheries Society. Manila. Philippines Asian Fisheries Science. 5: 25-36.

Mendoza, J. J. \& A. Larez. 1996. Abundance and Distribution of snappers and groupers targeted by artisanal medium-range fishery off Norhern Venezuella. ICLARM Conf. Proc. 48: 226-276.

Parish, J. D., 1987. The thropic biology of snappers and groupers. In Raipston, S. Polovina, J. J. (Eds.). Topal Snappers and Groupers: Biology and Fisheries Management. Westview Press. Boulder. 375-404.

Nuraini, S. 2007. Laju tangkap ikan kerapu (Grouper) dan kakap merah (Snapper) dengan pancing ulur dan tonda di perairan Kabupaten Berau, Kalimantan Timur. In Prosiding Konferensi Sains Kelautan dan Perikanan Indonesia I. Kampus Fakultas Perikanan dan IImu Kelautan-Institut Pertanian Bogor. Bogor. Dermaga. 17-18 Juli 2007.

Syahasta, D. G., Z. Asikin, Sutarno. \& M. Sabrawi. 2007. Laporan Kajian Penangkapan Rawai Dasar Berbasis Kapal Penampung Bergilir KUB di Probolinggo. Direktorat Jenderal Perikanan Tangkap. Balai Besar Pengembangan Penangkapan Ikan. Semarang. 99 pp. 